\title{
Cucumber seedling dependence on cotyledonary leaves for early growth
}

\author{
Dilson Antônio Bisognin(1), Luis Velasquez ${ }^{(2)}$ and Irvin Widders ${ }^{(3)}$
}

\begin{abstract}
(1)Universidade Federal de Santa Maria, Dep. de Fitotecnia, CEP 97105-900 Camobi, Santa Maria, RS, Brazil. E-mail: dilsonb@smail.ufsm.br (2)Michigan State University, Dep. of Plant Pathology, 48824, East Lansing, MI, USA. (3)Michigan State University, Dep. of Horticulture, 48824, East Lansing, MI, USA.
\end{abstract}

\begin{abstract}
The objective of this work was to evaluate the dependence of cucumber (Cucumis sativus L.) seedlings on cotyledonary leaves for early growth and establishment. Sets of two uniform emerging seedlings were used to quantify the initial growth and dry matter accumulation, as well as the intensity and stage of cotyledon damage in seedling establishment and to determine cotyledon protein, amino acid and carbohydrate contributions to the growing seedling. Cucumber seedling establishment was found to be highly dependent on cotyledonary leaves. Root system establishment was highly dependent on the health of the aerial part. One cotyledon was enough to maintain aerial growth of seedlings after unfolding the first true leaf. Cucumber seedlings depended on both cotyledons to keep root system growth at least until leaf area was equivalent to cotyledon area. Covering one or both cotyledons of seedlings with one unfolded leaf increased carbohydrate content of uncovered cotyledon and leaves compared with control seedlings. Cucumber seedlings are highly dependent on cotyledonary leaves and aerial parts are less dependent than root system. Cotyledon damage at early stages of plant establishment would adversely impact crop yield by reducing plant density, an important yield component, or slowing down seedling growth and establishment.
\end{abstract}

Index terms: Cucumis sativus, cotyledon excision, cotyledon coverage, dry matter, leaf area.

\section{Dependência das folhas cotiledonares para o crescimento inicial de pepino}

Resumo - O objetivo deste trabalho foi estudar o desempenho das folhas cotiledonares no crescimento inicial e estabelecimento de plântulas de pepino (Cucumis sativus L.). Grupos de duas plântulas uniformemente emergidas foram utilizados para quantificar o crescimento inicial e acúmulo de matéria seca, o efeito da intensidade e época de remoção dos cotilédones sobre o estabelecimento da plântula, e a contribuição de proteínas, aminoácidos e carboidratos dos cotilédones para o crescimento inicial. O estabelecimento das plântulas de pepino foi altamente dependente das folhas cotiledonares. As folhas cotiledonares foram fundamentais para o estabelecimento do sistema radicular. A presença de um cotilédone após a emissão da primeira folha verdadeira foi suficiente para manter o crescimento da parte aérea da plântula. Plântulas de pepino foram dependentes de ambas as folhas cotiledonares para sustentar o crescimento do sistema radicular, pelo menos até a equivalência entre área foliar e cotiledonar. A cobertura de uma ou ambas folhas cotiledonares antes da emissão da primeira folha verdadeira aumentou o conteúdo de carboidratos no cotilédone descoberto e nas folhas, comparado com a testemunha. O crescimento inicial de plântulas de pepino é altamente dependente das folhas cotiledonares, sendo a parte aérea menos dependente do que o sistema radicular. Danos nos cotilédones durante o crescimento inicial podem afetar o rendimento pela redução da densidade de plantas, um importante componente do rendimento, ou da taxa de crescimento e estabelecimento da plântula, que afeta a uniformidade da cultura.

Termos para indexação: Cucumis sativus, remoção de cotilédone, cobertura de cotilédone, matéria seca, área foliar.

\section{Introduction}

Cucumber (Cucumis sativus L.) has epigeal emergence, in which the hypocotyl pulls the cotyledons out of the soil after the initial development of primary and secondary roots (Nelson \& Larson, 1984). Cucumber cotyledons undergo a high rate of expansion growth after emergence, resulting from increases in cell size and number. A high rate of cotyledon expansion associated with chlorophyll production and presence of functional stomata made cucumber cotyledons adapted for photosynthesis (Lovell \& Moore, 1970). Cucumber seedling depends on seed reserves only during the preemergence growth. Further seedling development 
depends on photosynthetic activity of the leaf-like cotyledons (Penny et al., 1976). Early growth of species with leaf-like cotyledons is concentrated in the cotyledons themselves, hypocotyls and roots at the expenses of leaf development (Lovell \& Moore, 1971).

Given the assimilatory role of the cotyledons, any damage to them should have a negative effect on seedling development. Low temperature and soil crusting can damage the cotyledons; insect and disease attack can lead to a partial or a complete destruction of the cotyledons (Cantliffe \& Omran, 1981); and cotyledon cracking and seed coat attachment after germination can significantly reduce photosynthetic area of cotyledons. As a specific example, species of cucumber beetles (Diabrotica spp.) can cause major damages to cucumber seedlings. Cucumber beetles possess an extraordinary detoxification mechanism that enable these insects to grow, develop and reproduce on high toxic levels of cucurbitacins, an oxygenated tetracyclic triterpenoid produced as a secondary metabolite almost exclusively by cucurbit plants (Halaweish et al., 1999). Moreover, cucurbitacins trigger a compulsive feeding in cucumber beetle with no measurable loss in fitness (Deheer \& Tallamy, 1991).

Studies done on the contribution of cotyledonary leaves to cucumber seedling growth showed that cotyledon damage affects normal seedling development and might change plant patterns during later developmental stages. Removal of both cotyledons of the cucumber line 'MSU713-5' delayed pistillate flowering and removal of more than $25 \%$ of the cotyledonary area led to seedling growth reduction that went throughout plant maturity (Cantliffe \& Omran, 1981). The reduction in growth rate was equivalent to the reduction of photosynthetic surface of cucumber seedlings (Penny et al., 1976). Cotyledonary leaves were responsible for nearly $80 \%$ of the total net $\mathrm{CO}_{2}$ exchange of cucumber seedlings with only $50 \%$ of the total photosynthetic area (Lasley \& Garber, 1978). Therefore, a better understanding of cotyledonary leaves contribution to the initial growth and establishment of cucumber seedlings is necessary to evaluate how cotyledon damage can affect later plant development and in which stage cotyledon damage is more critical to adjust crop management and breeding strategies.

The objectives of this research were to evaluate the effect of different levels and times of cotyledon damage to seedling growth and the contribution of cotyledons to the protein, amino acid and carbohydrate concentrations in cucumber seedlings.

\section{Material and Methods}

\section{Plant material and experimental conditions}

Greenhouse experiments were conducted with the cucumber cultivar Calypso at Michigan State University from April to June, 2000. Four seeds were sown in $15 \mathrm{~cm}$ clay pots containing a medium comprised of $50 \%$ Baccto Mix (Michigan Peat Co., Houston) plus 50\% sandy loam soil. Seedlings were drip-irrigated daily to saturation. Seedlings were fertilized once a week following emergence with $20 \mathrm{~N}-20 \mathrm{P}_{2} \mathrm{O}_{5}-20 \mathrm{~K}_{2} \mathrm{O}$ soluble fertilizers at the concentration of $5 \mathrm{~g} \mathrm{~L}^{-1}$ of water. Day and night temperatures were about 30 and $20 \pm 5^{\circ} \mathrm{C}$, respectively, during the experimental period. No supplemental light was provided. The experimental design was completely randomized and one pot with two uniform emerging seedlings was considered an experimental unit.

\section{Experiment of initial growth quantifications}

Growth of cucumber seedlings was quantitatively characterized over time by destructively measuring cotyledon and leaf area and dry matter accumulation at 3-day intervals from emergence to 21 days after emergence (DAE) in four replications. The outlines of cotyledons and leaves were drawn on paper and the areas quantified based upon the relationship between cutout area and dry weight. Dry weight of cotyledons was determined after drying samples in a forced air oven at $65^{\circ} \mathrm{C}$ for 72 hours.

Cotyledons and leaves were excised at 3-day intervals from emergence to $21 \mathrm{DAE}$ to determine a time course trend in the concentration of total soluble carbohydrates, free amino acids and proteins in three replications. Fresh weight was recorded and samples were stored at $-20^{\circ} \mathrm{C}$ until processing. Sample processing and extraction of free amino acids and soluble carbohydrates were optimized for cucumber (Hwang et al., 1997). With a pre-chilled mortar and pestle, frozen cotyledon and leaf samples were ground to a powder state. A solution of $80 \%$ ethanol was added to the ground tissue in a ratio of 3:1 (v/w), ground for a few more seconds and $1 \mathrm{~mL}$ sample was transferred to Eppendorf tubes. The sludge was centrifuged at 10,000 rpm (Eppendorf 5415C, Eppendorf-Brinkmann Co., Westbury NY) for 20 min at room temperature. The clear supernatant was collected and stored at $-20^{\circ} \mathrm{C}$ until use for quantification 
of total free amino acids and carbohydrate concentrations. The pellet from the ethanol extraction was homogenized in $1 \mathrm{~mL}$ of $1 \mathrm{M}$ of $\mathrm{NaOH}$ and incubated for 2 hours at $37^{\circ} \mathrm{C}$. The homogenate was centrifuged at $10,000 \mathrm{rpm}$ for $10 \mathrm{~min}$ at room temperature. The supernatant was transferred to a new Eppendorf tube. The pellet was reextracted under the same conditions with an additional $0.5 \mathrm{~mL}$ of $1 \mathrm{M}$ of $\mathrm{NaOH}$ and the supernatant mixed with the previous extraction. The resulting greenish supernatant (about $1.5 \mathrm{~mL}$ ) was quickly stored at $-20^{\circ} \mathrm{C}$ until quantification of total protein.

The anthrone method was used to quantify total carbohydrates following manufacturer's specifications (Sigma Chemical Corp, St Louis, MO). An anthrone solution was prepared right before analysis by dissolving $0.1 \mathrm{~g}$ of anthrone in concentrated sulfuric acid. A total of $1.5 \mathrm{~mL}$ of anthrone and sulfuric acid solution was transferred to glass test tubes. Twenty-five $\mathrm{mL}$ of standard solution (with known concentrations of glucose) or cucumber samples were added in duplicates to the anthrone solution. The mixture was heated in a boiling water bath for $10 \mathrm{~min}$. Tubes were left to cool down at room temperature before reading the absorbance at $600 \mathrm{~nm}$ with a spectrophotometer (Varian Spectrophotometer Carry Series, Varian Inc., Palo Alto, CA). Total carbohydrate content was expressed per gram of fresh weight tissue.

Total free amino acids were quantified using ninhydrin reagent as described in Yemm \& Cooking (1955). A solution of 1:2 of ninhydrin reagent Ni632 (Sigma Chemicals, St. Louis, MO) and distilled water was prepared and $1 \mathrm{~mL}$ put into glass test tubes. A standard curve was prepared with leucine in $0.05 \%$ glacial acetic acid ranging from 0.1 to $1.5 \mathrm{mg} \mathrm{mL}^{-1}$. Twenty-five $\mathrm{mL}$ of standards or cucumber samples were added to the ninhydrin solution in duplicates and mixed by vortexing. Immediately, the tubes were placed in a boiling water bath for $10 \mathrm{~min}$. After the heat treatment, tubes were left to cool down at room temperature and $2 \mathrm{~mL}$ of $95 \%$ ethanol was added to each tube. Tubes were mixed by vortexing and absorbance was read at $570 \mathrm{~nm}$ in the spectrophotometer. Total free amino acids were expressed per gram of fresh weight tissue.

Bradford's method (Bradford, 1976) was used to quantify total protein content. The concentrated dye was prepared by diluting one part of dye agent (commercial kit for protein quantification, Biorad Inc., Hercules, CA) with four parts of water. A standard curve was prepared with bovine serum albumin ranging from 0.2 to $1.5 \mathrm{mg} \mathrm{mL}^{-1}$. One $\mathrm{mL}$ of the diluted dye was transferred to glass culture tubes. Ten $\mathrm{mL}$ of standards or cucumber samples were added to the dye solution in duplicates. They were immediately mixed by vortexing and incubated at room temperature for 5 min until color development and then read at $650 \mathrm{~nm}$ with the spectrophotometer. Total protein content was expressed per gram of fresh weight tissue.

\section{Cotyledon excision and coverage experiments}

One or both cotyledons were excised from cucumber seedlings at 3, 6, 9 and 12 DAE in four replications to simulate cotyledon loss due to insect predation. All treatments were evaluated at $21 \mathrm{DAE}$ and compared with control seedlings (with intact cotyledons) that were conducted together and at the same time. Below ground biomass was manually separated from substrata and washed in tap water. Dry weights of above ground shoots without cotyledons and below ground biomass was determined after drying samples in a forced air oven at $65^{\circ} \mathrm{C}$ for 72 hours.

One or both cotyledons were covered with aluminum foil to simulate an inhibition in photosynthesis and thus the ability to provide photoassimilates to growth and establishment of cucumber seedlings. Treatments were applied to a set of seedlings at 3, 6, 9 and 12 DAE in two replications. Cotyledons and leaves were harvested at 3-day intervals from 3 days after the treatment to 21 DAE along with cotyledons and leaves of control seedlings (with uncovered cotyledons). Fresh weights were recorded for all samples and then stored at $-20^{\circ} \mathrm{C}$ until processing. Sample processing, extraction and quantification of total soluble carbohydrate, free amino acid and protein contents of leaves and covered and uncovered cotyledons were done as described for initial growth quantifications of control seedlings.

\section{Statistical analysis}

All data was submitted to analysis of variance. Treatments of time and intensity of cotyledon excision and control were compared by Tukey's multiple range test at $\alpha=0.05$. Treatments of covering cotyledons and control were compared by pair wised t test at $\alpha=0.05$. These analyses were done with the statistical package GENES (Cruz, 2001). Covering treatments were also compared against control treatment by straight-line regression (Seber, 1976). Two straight lines of any 
comparison between control and covered treatments were first tested for parallelism. Linear parallel lines were tested for coincidence and non-parallel lines were tested for concurrence or intersection at origin. These statistical analyses were done using the procedures of Embrapa (1997).

\section{Results and Discussion}

Cotyledonary leaf area and dry matter accumulations of cucumber seedlings followed a time course trend that could be characterized by a non-linear sigmoid model (Figure 1). The model $\mathrm{y}=20.713 /\{1+\exp [-(\mathrm{x}-3.576) /$ 1.669] $\}$ with $\mathrm{R}^{2}=0.984$ was adjusted for cotyledon leaf area. The maximum daily accumulation rate was $3.10 \mathrm{~cm}^{2}$ plant $^{-1}$ estimated at 3.58 DAE. Based upon observed data, cotyledon area had a 14-fold increase from emergence to $21 \mathrm{DAE}$. The model $\mathrm{y}=80.427 /\{1$ $+\exp [-(\mathrm{x}-5.049) / 2.283]\}$ with $\mathrm{R}^{2}=0.948$ was adjusted for cotyledon dry matter. The maximum daily accumulation rate was $8.81 \mathrm{mg}$ plant $^{-1}$ estimated at 5.05 DAE. The non-linear exponential model $\mathrm{y}=0.849$ $+0.075 \exp (-\mathrm{x} /-4.537)$ with $\mathrm{R}^{2}=0.992$ was adjusted for the index of total (cotyledon and leaf area) by cotyledonary area. True leaf area reached the equivalence with cotyledonary area (when cotyledon and leaf area/cotyledon area is equal 2) at 12.4 DAE. A highrate increase of true leaf area began about 13 DAE with an observed daily growth rate of $18.0 \mathrm{~cm}^{2}$ plant $^{-1}$ day $^{-1}$ until the end of the experiment. This growth rate of true

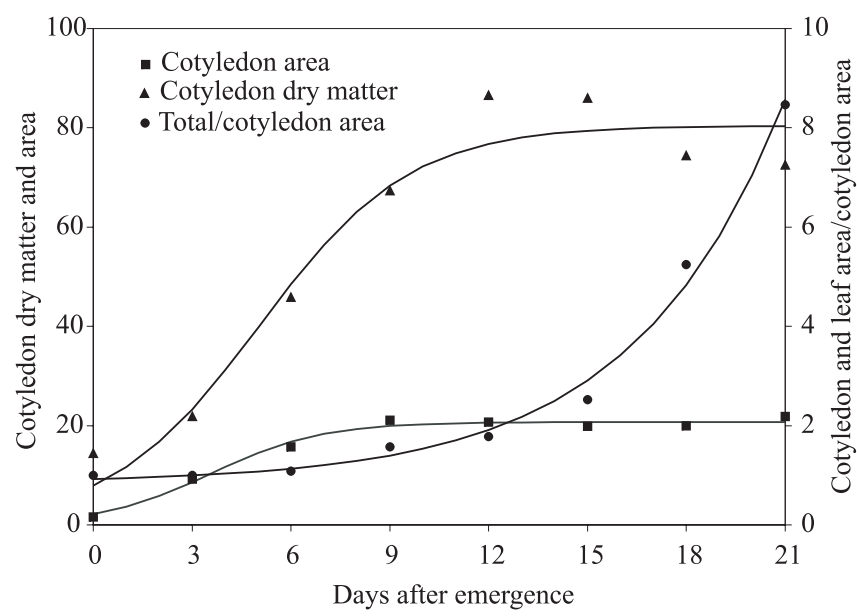

Figure 1. Cotyledonary area $\left(\mathrm{cm}^{2}\right.$ plant $\left.^{-1}\right)$, dry matter (mg plant ${ }^{-1}$ ) and index of total area (cotyledons and leaves) by cotyledonary area $\left(\mathrm{cm}^{2}\right.$ plant $\left.{ }^{-1}\right)$ accumulation of cucumber seedlings. leaf area was equivalent to an increase of $81.0 \%$ over total seedling cotyledon area each day after 13 DAE. Compared to other cucurbits, bottle gourd (Lagenaria siceraria Mol. Standl) seedlings reached the equilibrium between cotyledonary and leaf areas at 9 DAE (Bisognin et al., 1995) and hybrid squash cv. Tetsukabuto at 6 DAE (Amarante et al., 1995). As cotyledons have a relatively higher contribution (80\%) in total net $\mathrm{CO}_{2}$ exchange than true leaves when both areas were equivalent, cultural management strategies should be developed to prevent cotyledon damage at least until leaf area is equivalent to cotyledonary area.

There was a significant reduction in total protein, amino acid and carbohydrate concentration in cotyledons soon after emergence (Figure 2). The non-linear exponential models $\mathrm{y}=1.526+\{11.412[\exp (-\mathrm{x} / 6.201)]\}\left(\mathrm{R}^{2}=0.976\right)$ and $\mathrm{y}=0.176+\{2.713[\exp (-\mathrm{x} / 3.293)]\}\left(\mathrm{R}^{2}=0.997\right)$ were adjusted for protein and amino acid concentration in cotyledons, respectively. The polynomial regression $\mathrm{y}=0.721-0.029 \mathrm{x}\left(\mathrm{R}^{2}=0.966\right)$ was adjusted for
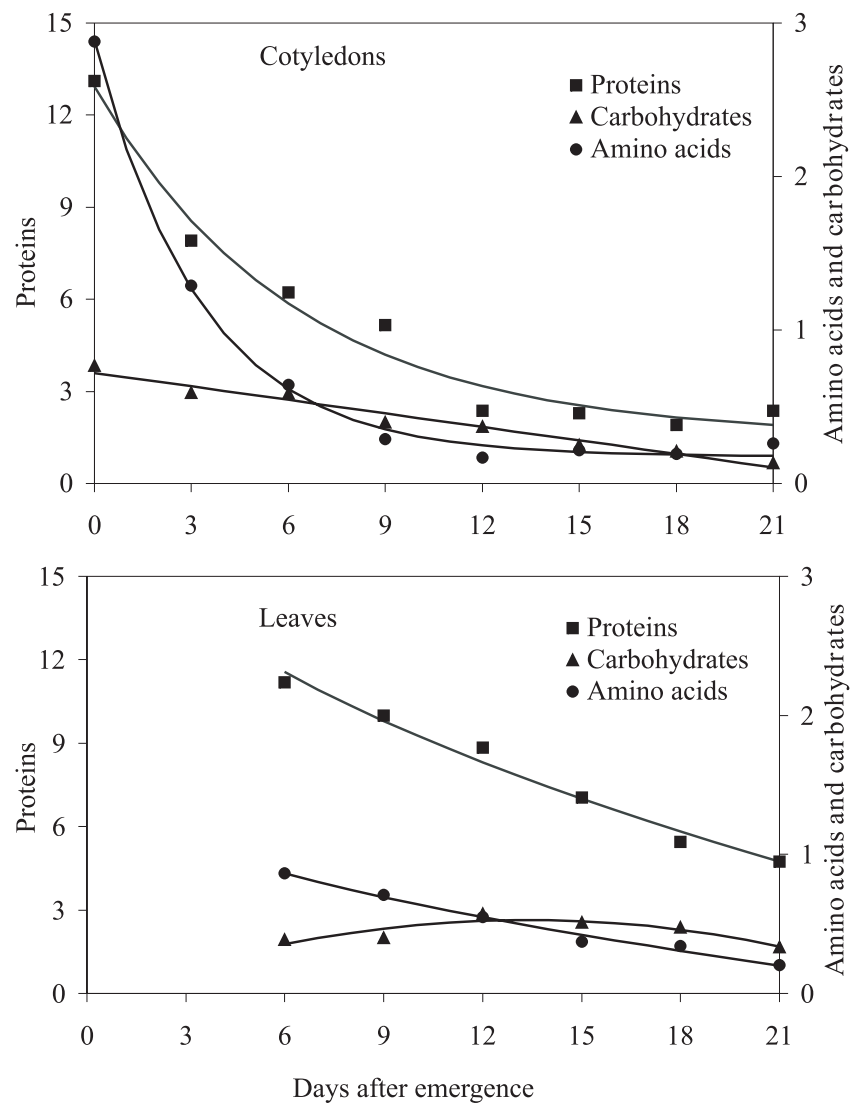

Figure 2. Total soluble protein, amino acid and carbohydrate concentrations (mg g-1 of fresh weight) in cotyledons and leaves of cucumber seedlings with intact cotyledons. 
carbohydrates. Soluble proteins had the highest observed concentration in cotyledons (12.7 $\mathrm{mg} \mathrm{g}^{-1}$ of fresh weight), followed by amino acids ( $2.8 \mathrm{mg} \mathrm{g}^{-1}$ of fresh weight), and carbohydrates $\left(0.7 \mathrm{mg} \mathrm{g}^{-1}\right.$ of fresh weight) at emergence. A similar trend for protein and amino acid concentration was observed in leaf tissues with the highest concentrations observed at $6 \mathrm{DAE}$, the stage when the first true leaf came out. The non-linear models $\mathrm{y}=19.380-3.194 \mathrm{x}^{0.5}\left(\mathrm{R}^{2}=0.982\right)$ and $\mathrm{y}=1.625-$ $0.311 x^{0.5}\left(R^{2}=0.989\right)$ were adjusted for protein and amino acid concentrations, respectively. The polynomial regression $\mathrm{y}=-0.051+0.087 \mathrm{x}-0.003 \mathrm{x}^{2}\left(\mathrm{R}^{2}=0.805\right)$ was adjusted for carbohydrate concentration.

In cotyledons, protein, carbohydrate and amino acid concentrations were diluted during expansive tissue growth after emergence. The development and increase in photosynthetic function occur concurrently with the increase in cotyledon area (Lovell \& Moore, 1970). Export of stored compounds and photoassimilates to other aerial organs and to the root system can explain further reductions in protein, amino acid and carbohydrate concentration in cotyledons. Stored proteins of cotyledons can be hydrolyzed to free amino acids, which are usually readily translocated to the rest of the growing seedling including roots. Translocation from cotyledons to support new leaf growth occurs because young leaves are not self-sufficient and are dependent upon external sources of assimilates for several days until net photosynthetic capacity has sufficiently developed. In leaves, the observed ontogenic trend was typical. Immature rapidly expanding leaf tissues were fully dependent upon phloem import of assimilates to sustain leaf tissue growth. As leaves further expand and mature, they changed from being net importers of photoassimilates to net exporters, contributing to the further growth of the young seedling (Hopkinson, 1964).

Seedling death occurred when both cotyledons were excised from cucumber seedlings at 3 DAE (Table 1). The excision of one cotyledon at $3 \mathrm{DAE}$ or both cotyledons at 6 DAE significantly reduced above ground (without cotyledons) dry matter production compared to control seedlings with intact cotyledons. The excision of one cotyledon at $6 \mathrm{DAE}$ or both cotyledons at $9 \mathrm{DAE}$ resulted in $24 \%$ reduction of above ground dry matter production. However, even the excision of one cotyledon at $12 \mathrm{DAE}$ resulted in a significant reduction of below ground biomass production (root dry weight). The reduction in root dry matter production varied from $35 \%$ to $100 \%$ compared to control seedlings. A higher coefficient of variation of below ground compared to above ground dry matter quantifications was expected, since not all roots could be recovered from the soil mixture in the containers.

Results from the excision experiment clearly established that below ground dry matter production had a longer dependence on cotyledonary leaves than above ground tissues. Moreover, reduction in initial seedling growth would be expected with the excision of even one cotyledon at $12 \mathrm{DAE}$, since the equivalence between cotyledonary and leaf area occurred at about the same time. At this seedling stage, cotyledons were responsible for $80 \%$ of total $\mathrm{CO}_{2}$ exchange (Lasley \& Garber, 1978). The longer dependence of roots on cotyledonary leaves might be associated with the source-sink relationship that is mostly regulated by tissue proximity (Taiz \& Zeiger, 1998). At the initial growth of cucumber seedlings, above and below ground tissues were close enough to cotyledons and both were highly affected when one cotyledon was removed. Additionally, cucumber seedlings did not survive when both cotyledons were removed. Aerial parts were still dependent on cotyledonary leaves up to $9 \mathrm{DAE}$ when growth could also be supported by true leaf photosynthesis. Keeping one intact cotyledon after 6 DAE was sufficient to partially support aerial seedling growth, but could not support root growth. When carbohydrate supply is

Table 1. Above (without cotyledons) and below ground dry matter (mg plant ${ }^{-1}$ ) of cucumber seedlings submitted to an excision of one or both cotyledons at 3, 6, 9, or 12 days after emergence (DAE) and percentage of reduction of treated compared to control seedlings (with intact cotyledons) evaluated at $21 \mathrm{DAE}^{(1)}$.

\begin{tabular}{|c|c|c|c|c|}
\hline \multirow[t]{2}{*}{ Treatments $^{(2)}$} & \multicolumn{2}{|c|}{ Above ground } & \multicolumn{2}{|c|}{ Below ground } \\
\hline & Dry matter & $\begin{array}{c}\text { Reduction } \\
(\%)\end{array}$ & Dry matter & $\begin{array}{c}\text { Reduction } \\
(\%)\end{array}$ \\
\hline Control & $495 a$ & 0.0 & $102 \mathrm{a}$ & 0.0 \\
\hline 1C12DAE & $454 a$ & 8.3 & $60 \mathrm{~b}$ & 40.8 \\
\hline 2C12DAE & $401 \mathrm{ab}$ & 19.0 & $52 \mathrm{bc}$ & 48.5 \\
\hline 1C9DAE & $498 \mathrm{a}$ & 0.0 & $67 b$ & 34.7 \\
\hline 2C9DAE & $375 \mathrm{ab}$ & 24.2 & $57 \mathrm{bc}$ & 44.2 \\
\hline 1C6DAE & $374 a b$ & 24.4 & $63 b$ & 38.6 \\
\hline $2 \mathrm{C} 6 \mathrm{DAE}$ & $159 c$ & 67.9 & $26 \mathrm{~cd}$ & 74.0 \\
\hline $1 \mathrm{C} 3 \mathrm{DAE}$ & $318 b$ & 35.7 & $57 \mathrm{bc}$ & 44.5 \\
\hline $2 \mathrm{C} 3 \mathrm{DAE}$ & Od & 100.0 & $0 \mathrm{~d}$ & 100.0 \\
\hline Average & 342 & 31.1 & 54 & 47.3 \\
\hline $\mathrm{CV}(\%)$ & 16.2 & & 25.4 & \\
\hline
\end{tabular}

${ }^{(1)}$ Means in columns followed by the same letter are not significantly different using Tukey's multiple range test at $\alpha=0.05$. (2)C: cotyledon; DAE: days after emergence for the excision of 1 or 2 cotyledons. 
reduced, in this case by the excision of one cotyledonary leaf, most of the available photosynthates is transported to stems and leaves at the expense of roots (Cooper \& Fransen, 1974; Penny et al., 1976; Marschner, 1997). In other words, root growth is primarily dependent upon photosynthates from cotyledons.

Total carbohydrate concentration of uncovered cotyledon was significantly higher than in control seedlings when treatments were applied at 6, 9 and 12 DAE (Table 2). The later the treatment was applied the higher was the carbohydrate concentration of uncovered cotyledon over time. One uncovered cotyledon older than 6 DAE was probable mature enough to produce photoassimilates to maintain total carbohydrate concentration in the tissue and to sustain aerial part growth, since the excision of one cotyledon with the same age did not significantly affect above ground dry matter production. This increase in carbohydrate concentration was also detected by pair wised t test at 18 and 21 DAE. No statistical differences were detected by straight-line regression analysis for total protein and amino acid concentration in the uncovered cotyledon when comparing any covered with control treatments. Pair wised t test showed some differences at 18 and $21 \mathrm{DAE}$ in total protein concentration with no clear trend. Covered cotyledon was completely decayed nine days after treatment.

Covering one or both cotyledons of cucumber seedlings at 6, 9 and 12 DAE significantly increased carbohydrate content in leaves compared with control

Table 2. Total protein, carbohydrate and amino acid concentrations in cotyledons of cucumber seedlings with both cotyledons or when one cotyledon was covered at 3, 6, 9, or 12 days after emergence (DAE) for evaluations at 3-day intervals from 3 days after treatment to $21 \mathrm{DAE}^{(1)}$.

\begin{tabular}{|c|c|c|c|c|c|}
\hline \multirow{2}{*}{$\begin{array}{l}\mathrm{DAE}^{(2)} \text { of } \\
\text { evaluation }\end{array}$} & \multirow[t]{2}{*}{ Control } & \multicolumn{4}{|c|}{ Remaining cotyledon when the other was covered at } \\
\hline & & $3 \mathrm{DAE}$ & $6 \mathrm{DAE}$ & $9 \mathrm{DAE}$ & $12 \mathrm{DAE}$ \\
\hline & \multicolumn{5}{|c|}{ Protein (mg g ${ }^{-1}$ of fresh weight) } \\
\hline 6 & $6.22 b$ & $7.25 \mathrm{a}$ & & & \\
\hline 9 & $5.17 \mathrm{a}$ & $5.15 \mathrm{a}$ & $4.55 \mathrm{a}$ & & \\
\hline 12 & $2.37 \mathrm{a}$ & $3.29 \mathrm{a}$ & $3.19 \mathrm{a}$ & $2.62 \mathrm{a}$ & \\
\hline 15 & $2.28 \mathrm{a}$ & $2.70 \mathrm{a}$ & $3.04 \mathrm{a}$ & $2.68 \mathrm{a}$ & $1.97 \mathrm{a}$ \\
\hline 18 & $1.91 \mathrm{~b}$ & $2.51 \mathrm{a}$ & $1.87 \mathrm{~b}$ & $2.20 \mathrm{ab}$ & $2.05 \mathrm{ab}$ \\
\hline 21 & $2.37 \mathrm{ab}$ & $2.81 \mathrm{a}$ & $1.65 \mathrm{~b}$ & $2.34 \mathrm{ab}$ & $2.28 \mathrm{ab}$ \\
\hline Parallelism & & ns & Ns & ns & ns \\
\hline Coincidence & & ns & Ns & ns & ns \\
\hline \multicolumn{2}{|l|}{ Concurrence } & ns & Ns & ns & $\mathrm{ns}$ \\
\hline & \multicolumn{5}{|c|}{ Carbohydrates ( $\mathrm{mg} \mathrm{g}^{-1}$ of fresh weight) } \\
\hline 6 & $0.59 a$ & $0.34 \mathrm{a}$ & & & \\
\hline 9 & $0.40 \mathrm{a}$ & $0.34 \mathrm{a}$ & $0.44 \mathrm{a}$ & & \\
\hline 12 & $0.37 \mathrm{a}$ & $0.33 a$ & $0.35 \mathrm{a}$ & $0.41 \mathrm{a}$ & \\
\hline 15 & $0.25 \mathrm{ab}$ & $0.15 b$ & $0.45 \mathrm{ab}$ & $0.42 \mathrm{ab}$ & $0.63 \mathrm{a}$ \\
\hline 18 & $0.21 \mathrm{c}$ & $0.14 \mathrm{c}$ & $0.53 \mathrm{a}$ & $0.55 \mathrm{a}$ & $0.37 b$ \\
\hline 21 & $0.13 c$ & $0.20 \mathrm{bc}$ & $0.36 \mathrm{ab}$ & $0.42 \mathrm{a}$ & $0.41 \mathrm{ab}$ \\
\hline Parallelism & & ns & $*$ & $* * *$ & $*$ \\
\hline Coincidence & & ns & $* *$ & $* * *$ & $* *$ \\
\hline \multicolumn{2}{|l|}{ Concurrence } & ns & ns & $*$ & ns \\
\hline & \multicolumn{5}{|c|}{ Amino acids ( $\mathrm{mg} \mathrm{g}^{-1}$ of fresh weight) } \\
\hline 6 & $0.64 a$ & $0.63 a$ & & & \\
\hline 9 & $0.29 b$ & $0.29 b$ & $0.49 \mathrm{a}$ & & \\
\hline 12 & $0.17 \mathrm{a}$ & $0.19 \mathrm{a}$ & $0.20 \mathrm{a}$ & $0.18 \mathrm{a}$ & \\
\hline 15 & $0.22 \mathrm{a}$ & $0.14 \mathrm{a}$ & $0.25 \mathrm{a}$ & $0.26 \mathrm{a}$ & $0.18 \mathrm{a}$ \\
\hline 18 & $0.19 a$ & $0.11 \mathrm{a}$ & $0.05 a$ & $0.10 \mathrm{a}$ & $0.18 \mathrm{a}$ \\
\hline 21 & $0.26 \mathrm{a}$ & $0.20 \mathrm{a}$ & $0.15 \mathrm{a}$ & $0.16 \mathrm{a}$ & $0.21 \mathrm{a}$ \\
\hline Parallelism & & ns & ns & $\mathrm{ns}$ & ns \\
\hline Coincidence & & ns & ns & ns & ns \\
\hline Concurrence & & ns & ns & $\mathrm{ns}$ & $\mathrm{ns}$ \\
\hline
\end{tabular}

${ }^{(1)}$ Means in rows followed by the same letter are not significantly different using pair wised test at $\alpha=0.05$; straight-line regression comparisons parallelism, coincidence and concurrence between control (uncovered cotyledons) against each of the covering treatments were done. (2)DAE: days

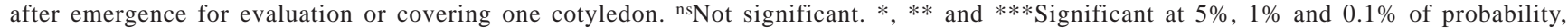
respectively. 
seedlings (Table 3). The later the treatment was applied the higher was the carbohydrate content 3 days after applying the treatment, as verified in uncovered cotyledon. Carbohydrate concentration was kept higher throughout the end of the experiment than in control seedlings. Pair wised t test showed that seedling with one or both cotyledons covered after 6 DAE had significantly higher carbohydrate concentration in leaves than control seedlings or submitted to other treatments. In most cases, covering one or both cotyledons did not change total protein and amino acid concentrations in leaves.

Since a linear regression model could explain the timecourse trends in total protein, carbohydrate and amino acid concentrations in cotyledon tissue of control seedlings, following $3 \mathrm{DAE}$, and in leaves, following 6 DAE, any treatment effect could be compared by straight-line regression (Seber, 1976). Total protein and amino acid concentrations were not affected in uncovered cotyledon or leaves of seedlings submitted to covering one or both cotyledons at 3, 6, 9 or 12 DAE. Protein and amino acid concentrations of control and treated seedlings followed the same trend of tissue dilution. These results showed that protein breakdown did not change significantly with a reduction in cotyledonary area and seedling dry matter production as a result of covering one or both cotyledons. A similar concentration of protein and amino acid in the tissue means that total amount in control seedlings was higher

Table 3. Total protein, carbohydrate and amino acid concentrations in leaves of cucumber seedlings with both cotyledons (control) or when one or both cotyledons were covered at 3, 6, 9, or 12 days after emergence (DAE) for evaluations at 3-day intervals from 3 days after treatment to $21 \mathrm{DAE}^{(1)}$.

\begin{tabular}{|c|c|c|c|c|c|c|c|c|c|}
\hline \multirow{2}{*}{$\begin{array}{l}\mathrm{DAE}^{(2)} \text { of } \\
\text { evaluation }\end{array}$} & \multirow[t]{2}{*}{ Control } & \multicolumn{4}{|c|}{ One cotyledon covered at } & \multicolumn{4}{|c|}{ Both cotyledons covered at } \\
\hline & & $3 \mathrm{DAE}$ & $6 \mathrm{DAE}$ & $9 \mathrm{DAE}$ & $12 \mathrm{DAE}$ & $3 \mathrm{DAE}$ & $6 \mathrm{DAE}$ & $9 \mathrm{DAE}$ & $12 \mathrm{DAB}$ \\
\hline & \multicolumn{9}{|c|}{ Protein $\left(\mathrm{mg} \mathrm{g}^{-1}\right.$ of fresh weight $)$} \\
\hline 6 & $11.20 \mathrm{a}$ & $9.04 \mathrm{a}$ & & & & $10.10 \mathrm{a}$ & & & \\
\hline 9 & $9.99 \mathrm{~b}$ & $12.56 \mathrm{a}$ & $9.77 \mathrm{~b}$ & & & $10.63 \mathrm{ab}$ & $9.44 b$ & & \\
\hline 12 & $8.84 \mathrm{ab}$ & $8.88 \mathrm{a}$ & $7.59 \mathrm{ab}$ & $6.73 b$ & & $9.45 \mathrm{a}$ & $7.52 \mathrm{ab}$ & $6.72 b$ & \\
\hline 15 & $7.05 \mathrm{ab}$ & $6.96 \mathrm{ab}$ & $4.94 \mathrm{~b}$ & $6.38 \mathrm{ab}$ & $6.32 \mathrm{ab}$ & $8.92 \mathrm{a}$ & $7.80 \mathrm{a}$ & $7.71 \mathrm{a}$ & $8.72 \mathrm{a}$ \\
\hline 18 & $5.45 \mathrm{ab}$ & $4.91 \mathrm{abc}$ & $5.36 \mathrm{ab}$ & 4.67abc & $4.16 \mathrm{bc}$ & $5.80 \mathrm{a}$ & $5.03 \mathrm{abc}$ & $3.83 \mathrm{c}$ & $4.31 b c$ \\
\hline 21 & $4.75 \mathrm{a}$ & $4.71 \mathrm{a}$ & $4.31 \mathrm{a}$ & $3.92 \mathrm{a}$ & $3.28 \mathrm{a}$ & $4.10 \mathrm{a}$ & $3.85 \mathrm{a}$ & $4.13 \mathrm{a}$ & $4.25 \mathrm{a}$ \\
\hline Parallelism & & ns & ns & ns & ns & $\mathrm{ns}$ & $\mathrm{ns}$ & $\mathrm{ns}$ & ns \\
\hline Coincidence & & ns & ns & ns & ns & ns & ns & ns & ns \\
\hline Concurrence & & ns & ns & $\mathrm{ns}$ & $\mathrm{ns}$ & ns & ns & $\mathrm{ns}$ & ns \\
\hline & \multicolumn{9}{|c|}{ Carbohydrates ( $\mathrm{mg} \mathrm{g}^{-1}$ of fresh weight) } \\
\hline 6 & $0.38 \mathrm{~b}$ & $0.36 \mathrm{~b}$ & & & & $0.83 \mathrm{a}$ & & & \\
\hline 9 & $0.40 \mathrm{~b}$ & $0.69 \mathrm{a}$ & $0.48 \mathrm{~b}$ & & & $0.44 b$ & $0.58 \mathrm{ab}$ & & \\
\hline 12 & $0.57 \mathrm{ab}$ & $0.30 \mathrm{~b}$ & $0.52 \mathrm{ab}$ & $0.59 \mathrm{ab}$ & & $0.31 b$ & $0.71 \mathrm{ab}$ & $0.96 \mathrm{a}$ & \\
\hline 15 & $0.51 b c$ & $0.32 \mathrm{c}$ & $0.85 \mathrm{ab}$ & $0.60 b c$ & $1.01 \mathrm{a}$ & $0.36 \mathrm{c}$ & $0.59 b c$ & $0.80 \mathrm{ab}$ & $1.16 \mathrm{a}$ \\
\hline 18 & $0.47 \mathrm{bc}$ & $0.60 \mathrm{abc}$ & $0.62 \mathrm{abc}$ & $0.92 \mathrm{a}$ & $0.76 \mathrm{abc}$ & $0.39 \mathrm{c}$ & $0.76 \mathrm{abc}$ & $0.88 \mathrm{ab}$ & $0.75 \mathrm{abc}$ \\
\hline 21 & $0.33 \mathrm{~d}$ & $0.47 \mathrm{~cd}$ & $0.99 \mathrm{a}$ & $0.53 \mathrm{bc}$ & $0.52 \mathrm{c}$ & $0.55 b$ & $0.77 \mathrm{ab}$ & $0.70 \mathrm{~b}$ & $0.77 \mathrm{ab}$ \\
\hline Parallelism & & ns & $* *$ & $*$ & $*$ & ns & $*$ & $*$ & $*$ \\
\hline Coincidence & & ns & $* * *$ & * & $* *$ & ns & $* * *$ & ** & ** \\
\hline Concurrence & & ns & ns & ns & ns & ns & ns & ns & ns \\
\hline & \multicolumn{9}{|c|}{ Amino acids ( $\mathrm{mg} \mathrm{g}^{-1}$ of fresh weight) } \\
\hline 6 & $0.87 \mathrm{a}$ & $1.73 \mathrm{a}$ & & & & $1.15 \mathrm{a}$ & & & \\
\hline 9 & $0.71 \mathrm{a}$ & $0.72 \mathrm{a}$ & $0.77 \mathrm{a}$ & & & $0.72 \mathrm{a}$ & $0.56 \mathrm{a}$ & & \\
\hline 12 & $0.55 \mathrm{ab}$ & $0.33 \mathrm{c}$ & $0.44 b c$ & $0.51 b$ & & $0.77 \mathrm{a}$ & $0.45 b c$ & $0.44 \mathrm{bc}$ & \\
\hline 15 & $0.37 \mathrm{ab}$ & $0.32 \mathrm{ab}$ & $0.20 \mathrm{c}$ & $0.27 b$ & $0.27 b$ & $0.25 b$ & $0.41 \mathrm{a}$ & $0.35 \mathrm{ab}$ & $0.40 \mathrm{a}$ \\
\hline 18 & $0.34 \mathrm{a}$ & $0.21 \mathrm{a}$ & $0.20 \mathrm{a}$ & $0.25 \mathrm{a}$ & $0.32 \mathrm{a}$ & $0.28 \mathrm{a}$ & $0.23 \mathrm{a}$ & $0.19 \mathrm{a}$ & $0.31 \mathrm{a}$ \\
\hline 21 & $0.20 \mathrm{a}$ & $0.34 \mathrm{a}$ & $0.21 \mathrm{a}$ & $0.18 \mathrm{a}$ & $0.28 \mathrm{a}$ & $0.22 \mathrm{a}$ & $0.23 \mathrm{a}$ & $0.23 \mathrm{a}$ & $0.28 \mathrm{a}$ \\
\hline Parallelism & & ns & $\mathrm{ns}$ & ns & ns & $\mathrm{ns}$ & $\mathrm{ns}$ & ns & $\mathrm{ns}$ \\
\hline Coincidence & & ns & ns & ns & ns & ns & ns & ns & ns \\
\hline Concurrence & & ns & ns & ns & ns & ns & ns & ns & ns \\
\hline
\end{tabular}

(1) Means in rows followed by the same letter are not significantly different using pair wised t test at $\alpha=0.05$; straight-line regression comparisons parallelism, coincidence and concurrence between control (uncovered cotyledons) against each of the covering treatments were done.

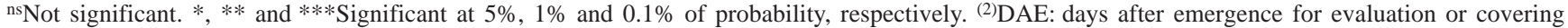
one cotyledon. 
than in treated seedlings based upon fresh weight, since growth rate reduction was equivalent to the seedling photosynthetic area as already verified in cucumber (Penny et al., 1976).

Differences in total carbohydrate status of cucumber seedlings would be expected in treated seedlings if they had higher leaf carbohydrate concentrations than those in control seedlings. Seedlings in which cotyledons were excised after the emergence of the first true leaf (6 DAE) exhibited increased leaf tissue carbohydrate concentration as compared to control seedlings or seedlings treated at $3 \mathrm{DAE}$. At $3 \mathrm{DAE}$, cucumber seedlings were highly dependent on cotyledonary leaves and even the excision of one cotyledon resulted in a significant reduction of above and below ground dry matter production. Considering that seedlings with reduced growth rate have a lower demand for photoassimilates and reserves to sustain growth of apices and new leaves than normal seedlings, part of the small amount of photoassimilates produced by the first true leaf or by the remaining cotyledon of seedlings treated after 6 DAE could be stored in the tissue as opposed as seedlings treated at 3 DAE when cotyledons accounted for all photosynthetic area.

Cotyledonary leaves have an important role in early cucumber seedling growth. Shoot growth was clearly less dependent upon assimilates from the cotyledons than root growth. One cotyledon following 9 DAE was sufficient to sustain aerial part growth, but even the excision of one cotyledon at 12 DAE significantly reduced root growth. Cucumber seedlings with $12 \mathrm{DAE}$ had the second true leaf emerged when leaf area was comparable to cotyledonary area. Changes in sink-source relationship during leaf maturation have been correlated with enzyme activity and leaf morphology. There is a shift from sucrose hydrolysis to sucrose synthesis and a rapid decrease in number of plasmodesmata, and thus in symplasmic isolation from the phloem during leaf maturation (Marschner, 1997). In cucumber leaves, sinksource shift occurred at the beginning of the fast increase phase of leaf area expansion reaching the maximum carbohydrate export together with maximum leaf area (Hopkinson, 1964). It seemed that aerial tissues were highly dependent on cotyledons until the first true leaf was completely unfolded, but root system dependence on cotyledonary leaves maybe last until cotyledon senescence. Root growth is also more affected than shoot growth when seedlings have some reduction in photosynthetic capacity, because root growth is dependent on photosynthetic rate (Marschner, 1997). Moreover, experimental evidence indicates that cotyledonary leaves are the primary photosynthetic organ exporting assimilates to the root system during early cucumber seedling growth, emphasizing the importance of sustaining cotyledonary leaf functionality during early plant ontogeny. Reductions of root system growth would likely limit the seedling's capacity to absorption of water and mineral nutrients especially those with low mobility (Marschner, 1997).

Cucumber growers must be aware about controlling biotic and abiotic factors that can cause any damage to cotyledons to get a uniform crop establishment, fruit set and maturation. As a consequence of cotyledon damage, depending on time and level, cucumber seedlings may or may not survive. Visual health of above ground tissues could mask growth reductions of root system due to cotyledon damage. Mechanical or insect lost of cotyledons, disease infection or chilling injury can effectively reduce photoassimilate production even after expansion of the first true leaf. Cucumber beetles usually cause major damage to cotyledons, because they are preferentially attracted for feeding by tissues with high cucurbitacin content (Chambliss \& Jones, 1966). Stress to young seedlings can delay and diminish pistillate flowering duration (Cantliffe \& Omran, 1981) that may affect cucumber total and/or commercial yield.

\section{Conclusions}

1. Cucumber cotyledonary leaves have an important role in early seedling growth and establishment.

2. Aerial organs are highly dependent on cotyledonary leaves until the first true leaf is completely unfolded, but root system dependence may last until senescence.

3. In cotyledons, protein, carbohydrate and amino acid contents are reduced after emergence doing to expansive growth and translocation to other aerial organs and root system.

\section{References}

AMARANTE, C.V.T.; BISOGNIN, D.A.; CANCI, P.C. Contribuição das folhas cotiledonares para o crescimento inicial de plantas de abóbora híbrida cv. Tetsukabuto. Ciência Rural, v.25, p.17-21, 1995.

BISOGNIN, D.A.; AMARANTE, C.V.T.; NICHIMORI, K.H. Análise do crescimento inicial de plantas de porongo (Lagenaria siceraria). Horticultura Brasileira, v.13, p.163-166, 1995. 
BRADFORD, M.M. A rapid and sensitive method for the quantification of microgram quantities of protein utilizing the principle of dye binding. Analytical Biochemistry, v.72, p.248254, 1976.

CANTLIFFE, D.J.; OMRAN, A.F. Alteration of sex expression in cucumber by partial or total removal of the cotyledons. Journal of American Society of Horticultural Science, v.106, p.303-307, 1981.

CHAMBLISS, O.L.; JONES, C.M. Cucurbitacins: specific insect attractants in cucurbitaceae. Science, v.153, p.1392-1393, 1966.

COOPER, C.S.; FRANSEN, S.C. Contribution of cotyledons to growth of the sainfoin seedling. Crop Science, v.14, p.732-735, 1974.

CRUZ, C.D. Aplicativo computacional em genética e estatística. Programa genes - versão windows 2001.0.0. Viçosa: Universidade Federal de Viçosa, 2001. 642p.

DEHEER, C.J.; TALLAMY, D.W. Affinity of cucumber beetle (Coleoptera: Chrysomelidae) larvae to cucurbitacins. Environmental Entomology, v.20, p.1173-1175, 1991.

EMBRAPA. Ambiente de software NTIA: manual do usuário ferramental estatístico. Campinas: Embrapa, 1997. 257p.

HALAWEISH, F.T.; TALLAMY, D.W.; SANTANA, E. Cucurbitacins: a role in cucumber beetle steroid nutrition? Journal of Chemical Ecology, v.25, p.2373-2383, 1999.

HOPKINSON, J.M. Studies on the expansion of the leaf surface: IV. The carbon and phosphorus economy of a leaf. Journal of Experimental Botany, v.15, p.125-137, 1964.

HWANG, B.K.; SUNWOO, J.Y.; KIM, Y.J.; KIM, B.S. Accumulation of beta-1,3-glucanase and chitinase isoforms, and salicylic acid in the DL-beta-amino-N-butyric acid-induced resistance response of pepper stems to Phytophthora capsici. Physiological and Molecular Plant Pathology, v.51, p.305322, 1997.

LASLEY, S.E.; GARBER, M.P. Photosynthetic contribution of cotyledons to early development of cucumber. HortScience, v.13, p.191-193, 1978.

LOVELL, P.H.; MOORE, K.G. A comparative study of cotyledons as assimilatory organs. Journal of Experimental Botany, v.21, p.1017-1030, 1970.

LOVELL, P.H.; MOORE, K.G. A comparative study of the role of the cotyledon in seedling development. Journal of Experimental Botany, v.22, p.153-162, 1971.

MARSCHNER, H. Mineral nutrition of higher plants. $2^{\text {nd }}$ ed. London: Academic Press, 1997. 492p.

NELSON, C.J.; LARSON, K.L. Seedling growth. In: TESAR, M.B. (Ed.). Physiological basis of crop growth and development. Madison: Library of Congress; American Society of Agronomy and Crop Science Society of America, 1984. p.93-129.

PENNY, M.G.; MOORE, K.G.; LOVELL, P.H. The effect of inhibition of cotyledon photosynthesis on seedling development in Cucumis sativus L. Annual Botany, v.40, p.815-824, 1976.

SEBER, G.A.F. Linear regression analysis. New York: John Wiley, 1976. 465p.

TAIZ, L.; ZEIGER, E. Plant physiology. $2^{\text {nd }}$ ed. Sunderland: Sinauer Associates Publishers, 1998. 793p.

YEMM, E.W.; COOKING, E.C. The determination of amino acids with ninhidrin. Analyst, v.80, p.209-213, 1955. 